\title{
TRANSITION AND AGRICULTURAL COOPERATIVES IN BULGARIA
}

\author{
Darina Zaimova, ${ }^{1}$ Julia Doitchinova, ${ }^{2}$ George Zheliazkov ${ }^{3}$
}

\begin{abstract}
One general characteristic of Eastern European countries (EEC) countries is that at the early stage of transition from a central-planned to a market economy the majority of land was returned to the rural population, which resulted in large numbers of relatively small and dispersed land plots. Geographical proximity and the similar institutional model of these countries identify common development constraints: generally small farm sizes, unclear cooperative legislation or inappropriate taxation policies, individualism and general unwillingness by the farmers to collaborate, absence of value chain activities and entrepreneurial spirit. This paper is purposed towards identifying, analyzing and evaluating the causes of economic and social changes in the development of agricultural cooperatives in Bulgaria in the past two decades.
\end{abstract}

JEL Classification Numbers: Q13, Q18; DOI: http://dx.doi.org/10.12955/cbup.v5.974

UDC Classification: 334,338

Keywords: Bulgaria, agriculture, cooperative model, development

\section{Introduction}

One general characteristic of Eastern European countries (EEC) is that at the early stage of transition from a central-planned to a market economy the majority of land was returned to the rural population, which resulted in large numbers of relatively small and dispersed land plots. Geographical proximity and the similar institutional model of these countries identify common development constraints: generally small farm sizes, unclear cooperative legislation or inappropriate taxation policies, individualism and general unwillingness by the farmers to collaborate, absence of value chain activities and entrepreneurial spirit. Political and cultural environments may be barriers to the adoption of collective action, as well as a perceived complication in setting up cooperative channels. The lack of knowledge of how cooperatives function also plays a role, as does the consequences of historical and political events, financial and land reform and fragmentation.

\section{Cooperative concept from perspective of the transition process}

Hillborn (1998) addressed cooperatives as schools of democracy being acknowledged for their significant role and impact over the turbulent process of transformation of the European map. Several authors recognized cooperativism as a process of shaping community culture and economic growth, especially in rural areas (Chloupková, 2002). Still it was also recognized as a core element of building a new model of society urged by the discrepancies within social classes, and inspired by the socialist ideology. Being part of the planned economy, cooperatives grew in scale to structure the state production and working system (Schilthuis et al., 2000). Cooperative relationships were imposed, instead of being built as a credible commitment based on the principles of mutualism and social economy. Their natural feature of being primarily economic enterprises driven by the market principles was also violated, which prevented cooperatives in certain Eastern European countries to develop and contribute as a steady mechanism for economic and social development.

Offe (1991) argues for a triple transition of the post-communist regimes: the transition to statehood, the transition to a capitalist economy, and the transition to a democratic political regime (Jan Steijn, 2007). According to Bryant and Mokrzycki (1994) we have witnessed the exhaustion of the development potential of the state socialist mode of production and the inability of communist partystates to resist demands for transformative change. Even more, there is neither model nor precedent for the transition from real socialism to democracy and capitalism. Kornai (1986) also states that the limits of reforming socialist economy were reached. The "gradualist" or evolutionary" approach of changing the system by partial and phased reforms was to keep lower social costs and also to deliver sustainable standards of life.

Political change in Bulgaria and the radical shift of control over production from state to private entities was considered as an essential step, which automatically would lead to market improvement;

\footnotetext{
${ }^{1}$ Darina Zaimova, Trakia University, Bulgaria, dzaimova@gmail.com

2 Julia Doitchinova, Trakia University, Bulgaria, juliadoj@abv.bg

${ }^{3}$ George Zheliazkov, Trakia University, Bulgaria, george-zh@mbox.digsys.bg
} 
economic criteria application, and irreversibility of the reforms under way. Nevertheless, the results were far from the expected optimistic ones instead leading to institutional instability, declining economic sectors, insufficient level of domestic demand, restricted export.

High physical fragmentation of land imposed significant constraints to farming and the development of the agricultural sector. This brings foward three key factors, which Swinnen (1997) hypothesizes to have constrained or influenced governments in their choice of land reform strategy: the precollectivization concentration of land ownership together with postcollectivization ownership status; the ethnicity of precollectivization owners; and the equality of postcollectivization asset distribution. This refers to the more recent interpretations, specific to Eastern European theorists, who draw on the sociopolitical reasons for avoiding cooperatives as organizational form in certain economic sectors. Burawoy and Verdery (1999) suggest a property analysis that evokes the total system of social, cultural and political relationships. Sabates-Wheeler (2005) acknowledges that while the evidence against the existence of economies of scale are robust, and empirical research indeed shows that free-riding and labor incentive problems do plague large collective farms.

\section{Logic framework and context analysis}

A step-wise approach is employed to build a conceptual framework for comprehending and analyzing cooperativism and its institutional environment specific factors for Bulgaria; and to also share the knowledge about the role of the various actors involved in stimulating and promoting cooperative movement (Table 1).

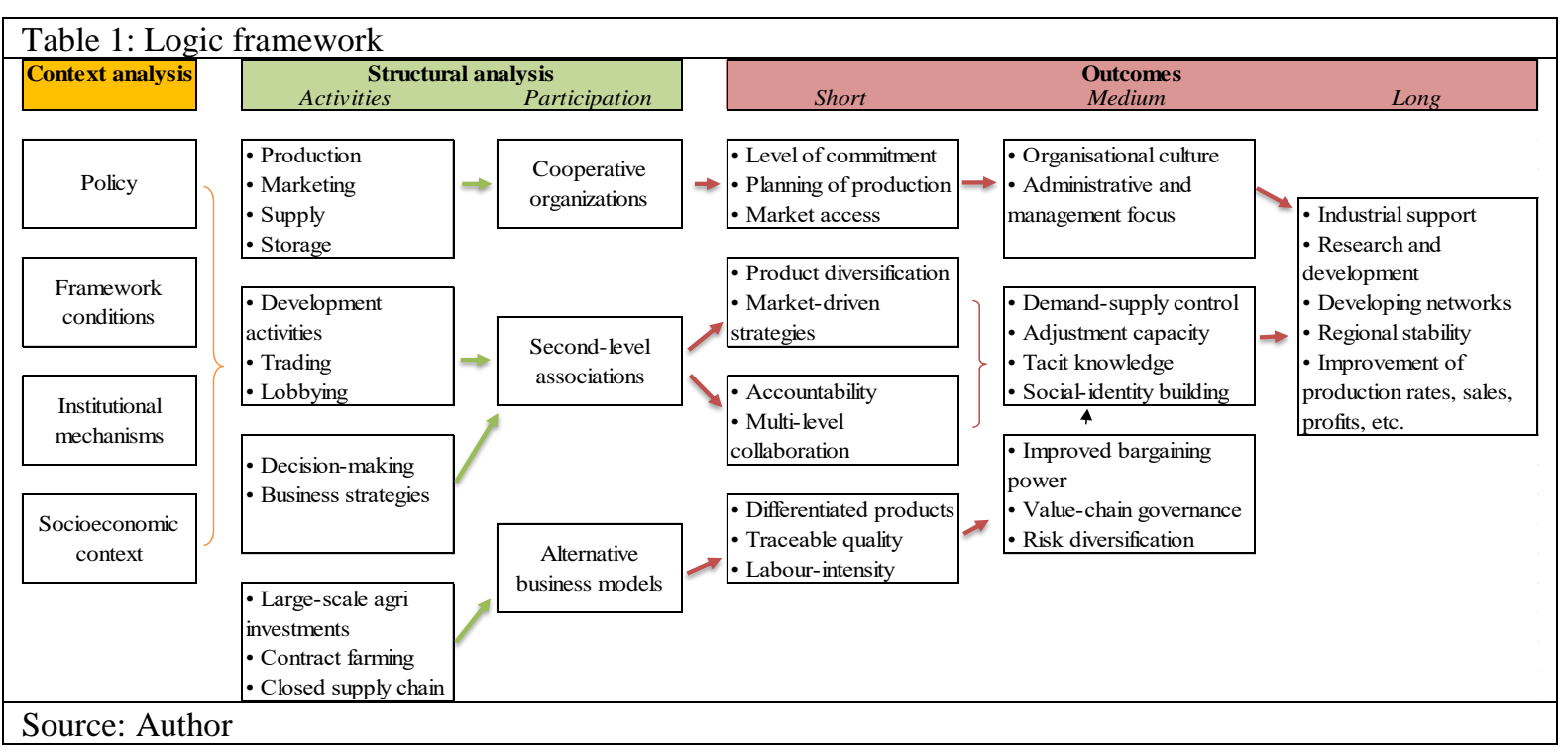

The analytical framework involves the following key elements: the role of the institutional framework and policy instruments; cooperative development within agricultural sector versus alternative business models, incl. single farming; and expected outcomes and positive co-relation.

In 1998 as a result from the restitution process $75 \%$ of the agricultural lands in Bulgaria were restored to their previous owners. The strong polarization in the size of the land farms was confirmed by the results from the Census of agricultural farms in 2003. Statistics signify for a prevailing number of small-scale farms (0.1-0.3 ha) and a small number of farms with over 50ha utilized agricultural land. By this period the EU was still concerned about the progress in the agricultural sector, where considerable efforts will be needed (European Commission, 1998). During the pre-accession period through the SAPARD program were allocated 52 million euro with the aim to improve agricultural production and the food-processing sector, and promote sustainable rural development. Over the period $2005-2007$ the process of reduction in all types of holdings, while increasing the average size of farms continued. According to the economic size of holdings, the largest group is the group of small farms i.e. farms having a size up to 4 economic units (more than $96 \%$ of total number of farm). $77.9 \%$ of the total number of holdings were up to 1 economic size unit, primarily subsistence farms; followed by farms having an economic size of $1-4$ economic size units, considered to be semi-subsistence farms. Results of the agricultural census in 2007 on the structure of the agricultural sector showed that 
the numbers of holdings in Bulgaria continued to decrease. Until 2007, the total number of holdings declined by $26.4 \%$ as the average size of farms increased by more than $42 \%$. The most substantial is the decline in number of cooperatives $(41.4 \%)$ followed by associations and others $(39.7 \%)$. A substantial re-distribution of land among the different legal type is observed as the area cultivated by cooperatives declined by nearly $38 \%$ as the land used by all other types of farms increased as the most substantial increase is observed in land used by companies.

\section{Structural analysis of the post-accession period}

Data Envelopment Analysis (DEA) is applied both to rate efficiency and to estimate sources and amounts of the inefficiency components for two consequent years - 2007 and 2008 - when significant institutional and economic stimuli have been provided to level up the organizational rate in the agricultural sector (Table 2).

\begin{tabular}{|c|c|c|c|}
\hline Output (Y) & & Input $(X)$ & \\
\hline \multirow{2}{*}{$\begin{array}{l}\text { Production } \\
\text { value }\end{array}$} & \multirow{2}{*}{$\begin{array}{l}\text { The value of economic } \\
\text { production that it is } \\
\text { produced and performed } \\
\text { (finished or unfinished) in } \\
\text { the } 2 \text { - year period. }\end{array}$} & $\begin{array}{l}\text { Utilized } \\
\text { Agricultural } \\
\text { Area }\end{array}$ & In hectares \\
\hline & & Salaries & $\begin{array}{l}\text { Employment costs for permanent and } \\
\text { seasonal labor }\end{array}$ \\
\hline \multirow[t]{2}{*}{ Sales } & \multirow[t]{2}{*}{$\begin{array}{l}\text { Total sales of products } \\
\text { and/or services in a trading } \\
\text { year. }\end{array}$} & $\begin{array}{l}\text { Production } \\
\text { costs }\end{array}$ & $\begin{array}{l}\text { Raw and consumable materials' cost, } \\
\text { services' cost, depreciation and amortization, } \\
\text { changes in raw and consumable materials' } \\
\text { inventories, contingencies' provisions }\end{array}$ \\
\hline & & $\begin{array}{l}\text { Operational } \\
\text { costs* }\end{array}$ & $\begin{array}{l}\text { Transport, quality control, sorting, } \\
\text { assembling, packaging, marketing costs }\end{array}$ \\
\hline \multicolumn{4}{|c|}{$\begin{array}{l}\text { * Operational costs include only these costs that are made at an organizational level for further processing of } \\
\text { production }\end{array}$} \\
\hline
\end{tabular}

Only for one year the number of cooperatives operating under CRS increases more than twice, positively influenced by the membership in producer organizations (cooperatives and limited liability company), which led to an adjustment and positive change in production, the pricing process and marketing (Graph 1).

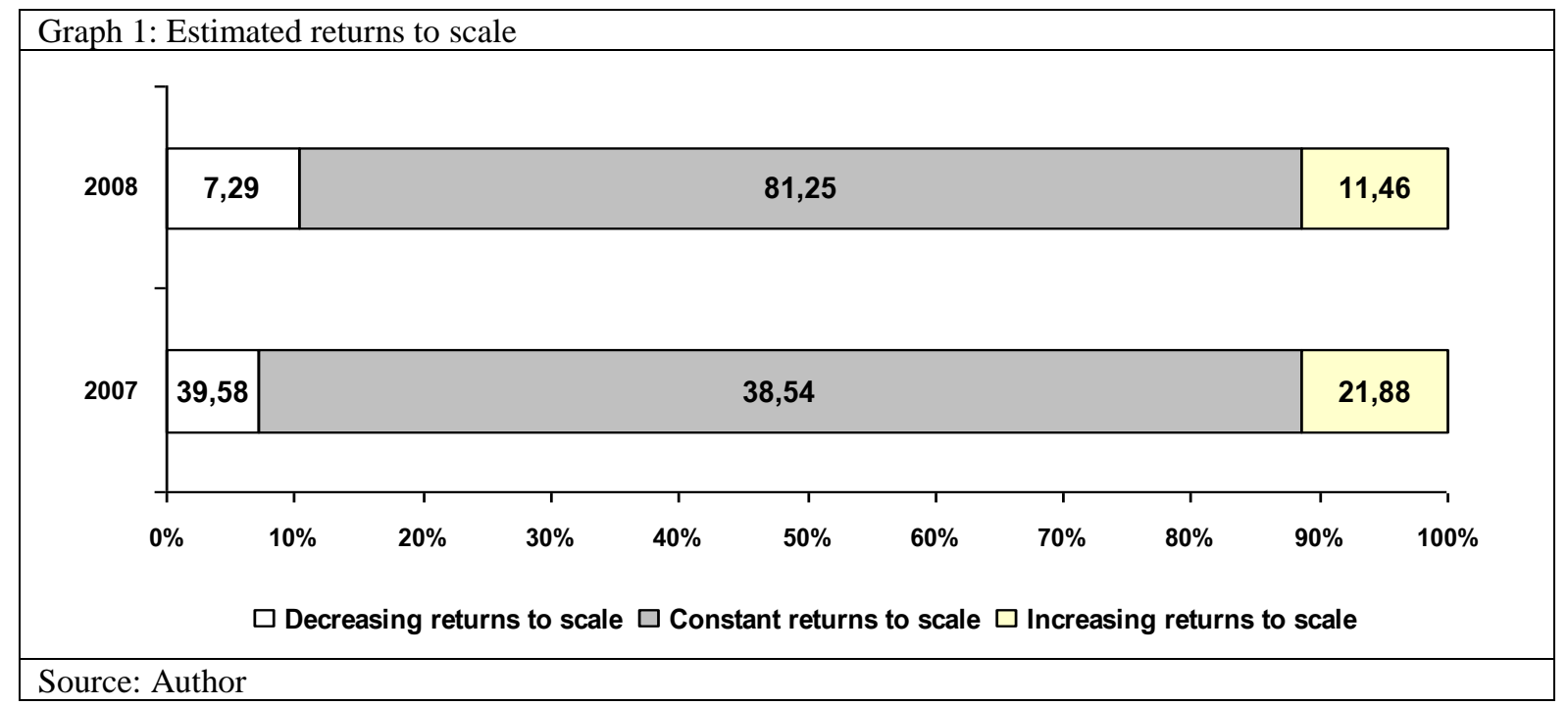

In 2007 the average efficiency result under constant returns to scale is 0.90 ; and as it has been expected under variable returns to scale the efficiency coefficient is higher amounting to 0.93 (Table 3 ). Of the total number of producers, under assumption for constant returns to scale $44 \%$ belong to the efficient production frontier or they are estimated as benchmarks with an efficiency coefficient of unity. This percentage increases slightly under variable returns to scale, when $56 \%$ of producers are estimated with unity efficiency coefficient. 


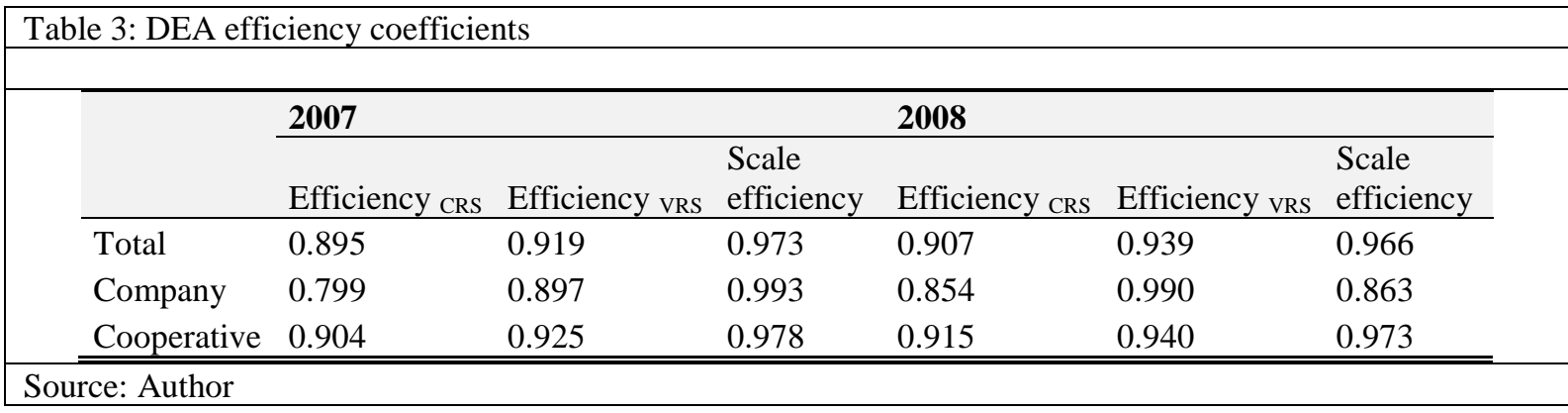

In 2008 the average efficiency coefficient estimated under constant returns to scale is 0.91 ; and under variable returns to scale the estimated coefficient is expectedly higher -0.94 . Almost $60 \%$ of decision-making units under variable returns to scale belong to the efficient frontier. Input optimization and the lower and the upper bounds of the stability region are calculated with the sensitivity analysis of both CRS and VRS (Table 4).

\begin{tabular}{|c|c|c|c|}
\hline \multirow{3}{*}{$\begin{array}{l}\text { Number of DMUs on the efficient } \\
\text { frontier }\end{array}$} & & 2007 & 2008 \\
\hline & CRS & $42 / 96$ & $43 / 96$ \\
\hline & VRS & $56 / 96$ & $57 / 96$ \\
\hline \multicolumn{2}{|c|}{ Number of DMUs with less than $10 \%$ request to decrease their inputs } & $92 / 96$ & $94 / 96$ \\
\hline \multicolumn{2}{|c|}{ Number of DMUs with more than $10 \%$ request to decrease their inputs } & $4 / 96$ & $2 / 96$ \\
\hline
\end{tabular}

The presented hypothetical frontier points of the minimum and maximum points of this increase are given in the percentage values of the lower and upper bounds in the following Graph 2 and Graph 3.
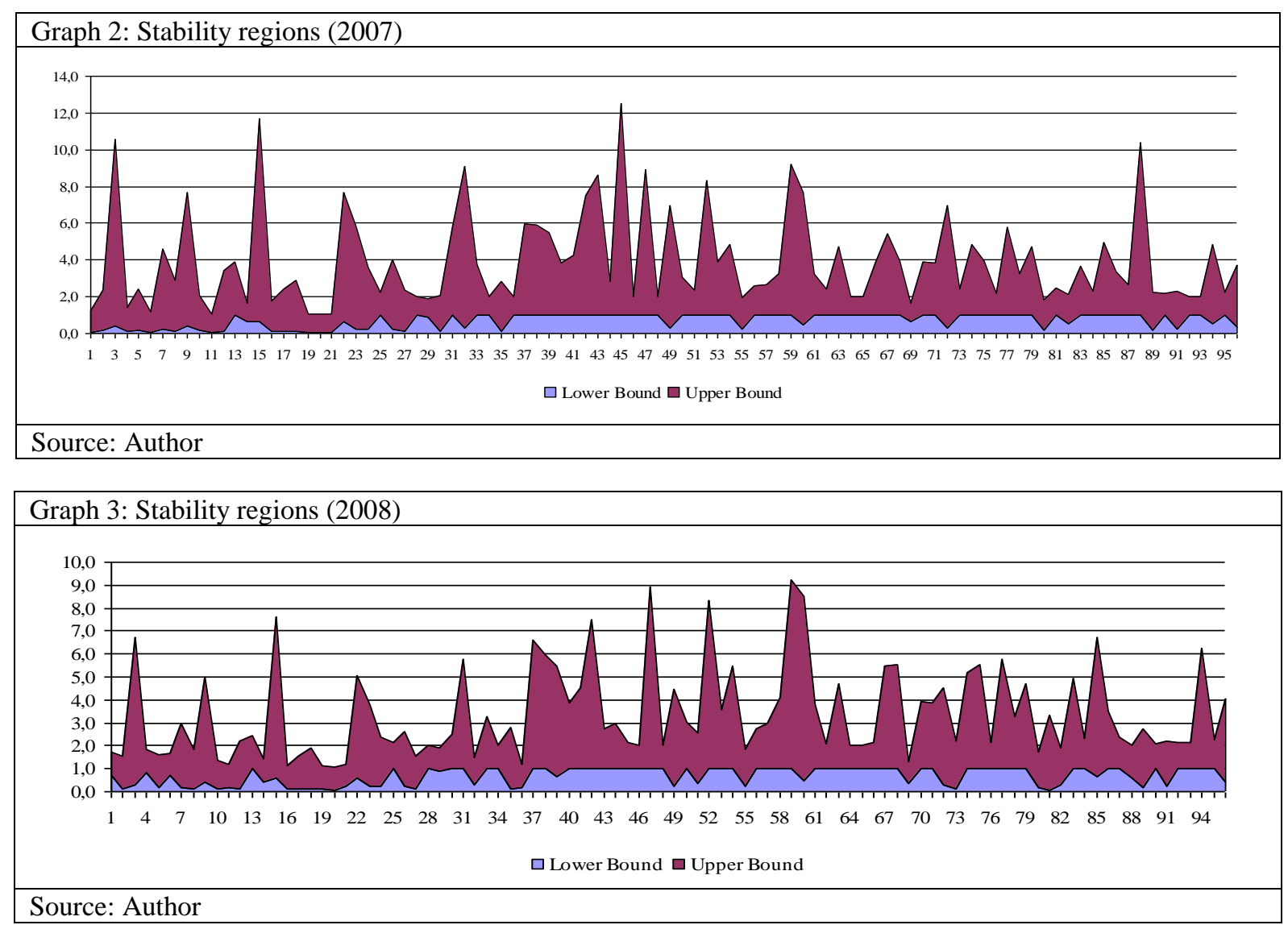

The calculated results reveal by how much the inputs could be increased, without influencing estimated efficiency levels. For producers with no calculated input slacks, it is expected that any increase in the input or decrease of the output will cause less efficiency. The relationship between input utilization, the efficiency coefficients and the size of utilized area is presented on Table 5. 


\begin{tabular}{|lllll}
\hline Table 5: Efficiency coefficients and size of producers \\
\hline & $\mathbf{2 0 0 7}$ & $\mathbf{2 0 0 8}$ & \\
\cline { 2 - 4 } & Efficiency CRS & Efficiency vRs & Efficiency cRs & Efficiency vRS \\
\hline Land & & & \\
\hline$>50 \mathrm{dca}$ & 0.548 & 1 & 0.517 & 1 \\
$<50 \mathrm{dca}$ & 0.777 & 0.745 & 0.806 & 0.636 \\
\hline Employment expenses & & & \\
\hline$>50 \mathrm{dca}$ & 0.865 & 0.865 & 0.865 & 0.865 \\
$<50$ dca & 0.204 & 0.684 & 0.164 & 0.680 \\
\hline Production costs & 0.882 & 0.886 & 0.804 & 0.797 \\
\hline Operational costs & 0.882 & 0.886 & 0.804 & 0.797 \\
\hline Source: Author & & & \\
\hline
\end{tabular}

As previously estimated members of cooperatives have managed to gain higher efficiency and to improve it during the period. The presented results show that the most efficient seem to be the largescale producers, who obtain significantly higher efficiency levels and achieve better economic performance. For 2007 the in-proportional change of used production inputs discloses that the optimization of the both costs categories - production and operational costs is close to $3.3 \%$ (Table 6). This change on average increases their efficiency results by $3.6 \%$. The most inefficiently utilized production resource appears to be the salary costs category - for 2007 the overall change in data set of this input on average is $23 \%$ and expectedly would improve efficiency by $25 \%$. Optimization of land input is in terms of redistribution of cultivated area and the average change among decision-making units in data set is $17.4 \%$ with expected efficiency improvement on average by $18.9 \%$. The percentage change in its redistribution is estimated to $11 \%$.

\begin{tabular}{|c|c|c|c|}
\hline & $\begin{array}{l}\text { Average change in } \\
\text { the data set }(\%)\end{array}$ & Optimal $\lambda(\%)$ & $\begin{array}{c}\text { Increase of the efficiency } \\
\text { coefficients }(\%)\end{array}$ \\
\hline UAA & 17.4 & 10.9 & 18.85 \\
\hline Salaries & 23.46 & 46.4 & 25.52 \\
\hline Production costs & 3.3 & 7.57 & 3.59 \\
\hline Operational costs & 3.3 & 7.57 & 3.59 \\
\hline
\end{tabular}

In 2008 there has been a change and redistribution in production and operational costs, which is estimated to $14 \%$ among the total decision-making units (Table 7). The optimization of the costs is estimated to $14 \%$ and it resulted in $1.5 \%$ increase of efficiency results. The estimated overall change in labour expenses is $16.3 \%$ and $14.29 \%$ of the costs have been decreased or redistributed to other budget items. The same conclusion is applicable to the utilized area input -14.2 percent of producers have redistributed on average $6.48 \%$ of their land input. This resulted in a $15.4 \%$ increase of the efficiency coefficients.

\begin{tabular}{|lccc|}
\hline \multicolumn{4}{|c|}{ Table 7: Sensitivity analysis (2008) } \\
\hline & $\begin{array}{c}\text { Average change in } \\
\text { the data set (\%) }\end{array}$ & Optimal $\boldsymbol{\lambda}$ (\%) & $\begin{array}{c}\text { Increase of the efficiency } \\
\text { coefficients (\%) }\end{array}$ \\
\hline UAA & 14.2 & 6.48 & 15.14 \\
Salaries & 16.3 & 14.29 & 17.43 \\
Production costs & 13.48 & 14.36 & 1.53 \\
Operational costs & 13.48 & 14.36 & 1.53 \\
\hline \hline
\end{tabular}

By the end of the studied period it is reasonable to look for a relationship between specialization of production and the obtained efficiency levels. Such supposition is consistent with the estimated significant relationship between the increased re-distribution of the agricultural area and the two cost categories - production and operational.

A Malmquist index comparative methodology is also applied to the present data set in order to measure the change of efficiency over time and the change in the efficient frontier (Appendix 1). 
Efficiency coefficients are decomposed into pure and scale efficiency. The calculated "catch up" effect does not signify for an increase in the relative efficiency, as the average coefficient of efficiency change is less than unity, estimated to 0.986 . This result could be interpreted as a regress or no change in the efficiency frontier. Therefore, a more detailed conclusion is provided by the calculated individual results. According to these, $19.8 \%$ of decision-making units have achieved catch-up effects with estimates more than 1 , which infers that they have managed to improve their efficiency. Producers who have experienced no change during the period represent $46.9 \%$ of the total evaluated units. The rest $33.3 \%$ have experienced regress in their efficiency. According to the type of registration - natural or legal person, there is significant improvement of producers who are registered as single persons and are members in a cooperative. This category of producers is among the estimated percentage for increase and no change in the efficiency frontier.

The last estimated coefficient "frontier shift" signifies whether efficiency change is due to improvement in production technology. The calculated frontier-shift effect signifies for slight progress in the frontier technology, as its value is 1.005 . Of the total number of producers $67.7 \%$ have indicated for progress in production technology and $30.2 \%$ experienced regress in production technology. Only 2 producers remained with no change in their efficiency level - positive or negative in their production technology.

The average value of the Malmquist index is 0.991 ; which is close to unity, but still according to the theoretical explanations signifies for the deterioration in the total factor productivity. This result is mostly justified by the small percentage of producers that have managed to improve their efficiency.

One of the most hopeful prospects derived from the performed analysis is that cooperatives have managed to prove their competitiveness along with the company not only in terms of achieved efficiency results, but also considering their sustainability during the studied period (Graph 4).

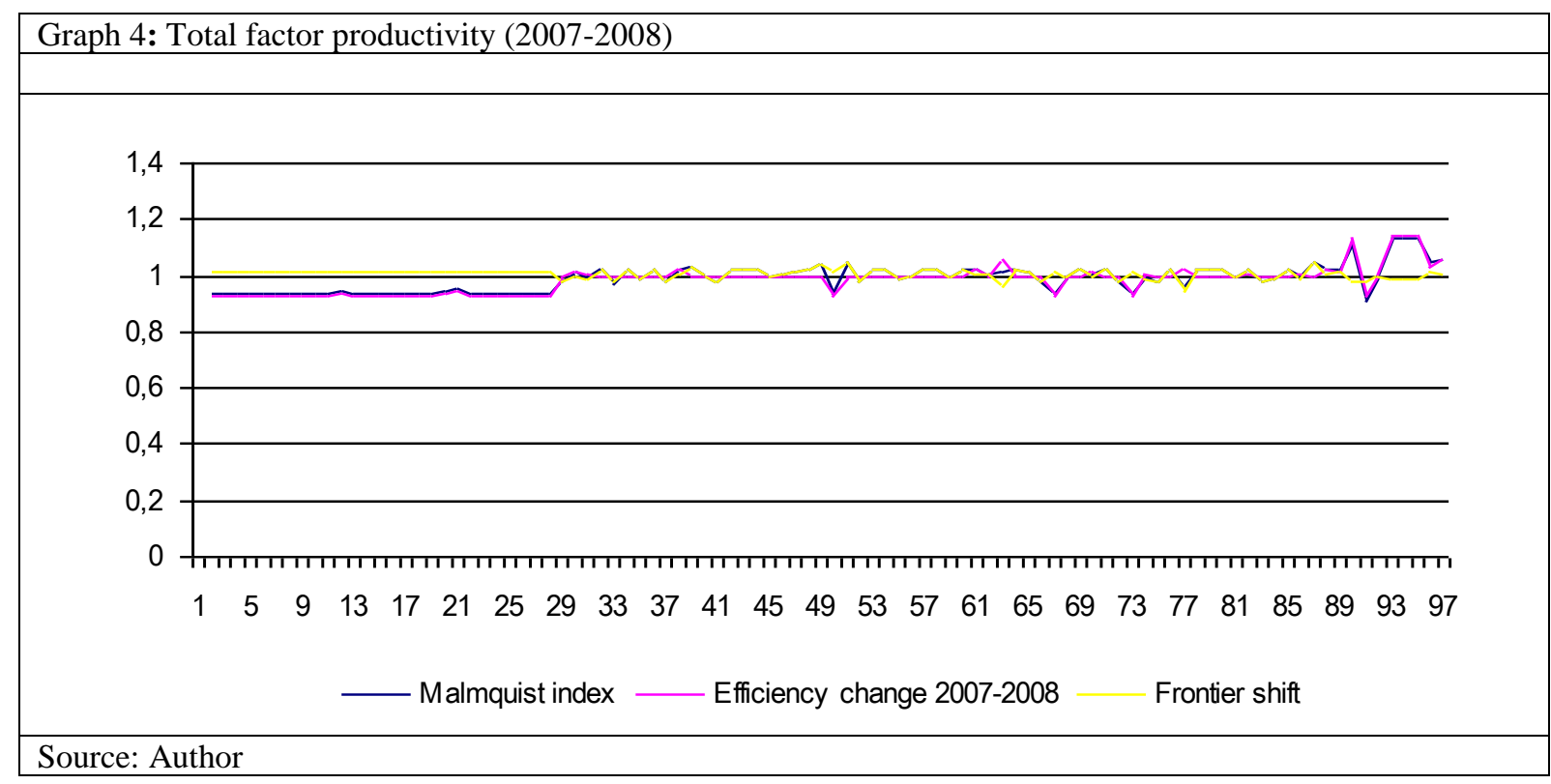

The decision-making process is revealed as a permanent process and consequences from each decision-making phase have particular impact not only over the individual producer, but also over the organization once he decides to become a member. Taking into account that the majority of problems, which an agricultural producer faces stem from inefficient organizational structures, collective organization of production is assumed to be a sufficient choice.

Several reasons could be pointed in favor of the assumption that cooperatives promote efficiency, such as: increase in optimal scale; reduction of transaction costs; engagement in different but complementary activities and thus releasing scale economies; and improvement of management and internal organizational coordination and control as well.

Results and achievements during the first programme period (2007-2013) and priorities for the second programme period (2014-2020) 
During the first programming period, there have been substantial structural changes, resulting in the increased importance of commercial companies and holdings of sole traders, while at the same time limited role of the agricultural cooperatives. In 2010, the largest amount of land is managed by farms owned by individuals ( $34 \%$ of UAA) followed by commercial companies (31.6\% of UAA). Compared to 1998 only $27.5 \%$ of the cooperatives are functioning, even more in some regions the land cultivated by cooperatives has declined by more than 10 times. At the end of the first programming period, cooperatives handle less than $15 \%$ of the total agricultural land.

In 2014 the number of registered agricultural producers has almost reached statistics at the beginning of the period (Graph 5).

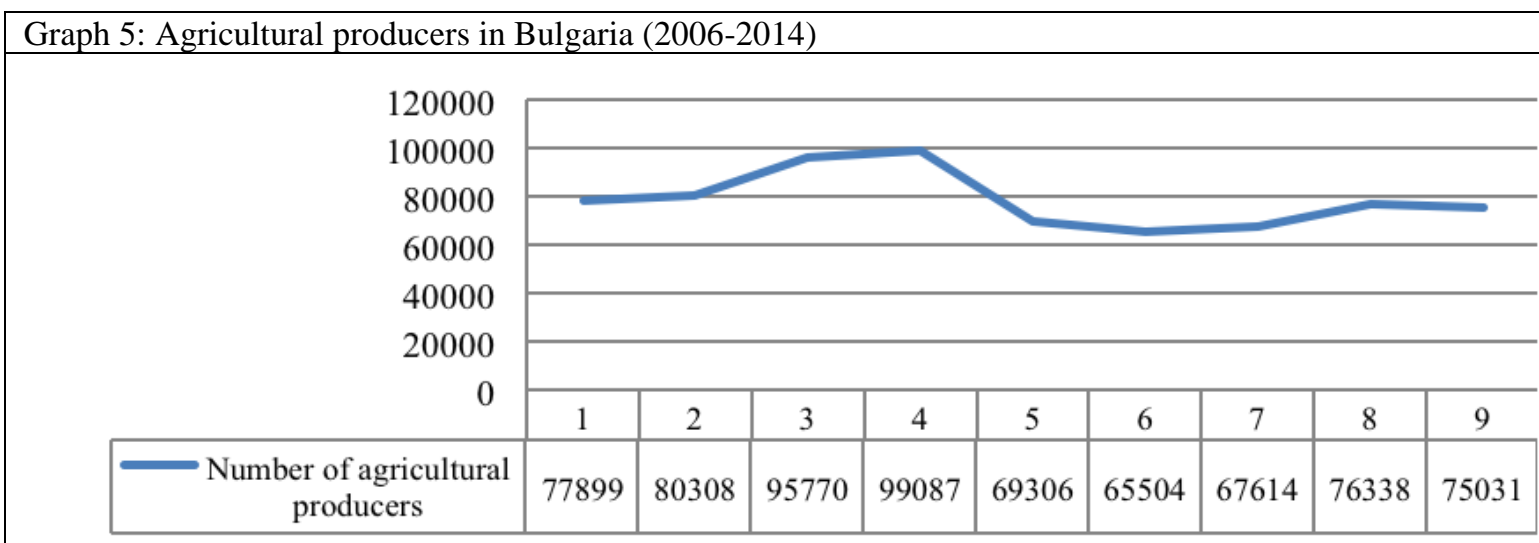

Source: Department "Agro statistics" Ministry of Agriculture and Food in Bulgaria

Increasing awareness of the role of agricultural cooperatives in reducing poverty and improving food security; facilitating the formation of agricultural cooperatives' networks, and supporting the development of enabling environments and better governance frameworks for agricultural cooperatives is perceived as a mission to create sustainable rural employment through business models that are more resilient to economic, social and environmental problems.

The rural development program for the program period 2014-2020 is built therefore upon six thematic priorities and fifteen priority areas aimed at program interventions, innovations and transfer of knowledge, etc. (Table 8).

\begin{tabular}{|cc|}
\hline Table 8: Development priorities of the two program periods \\
\hline $\begin{array}{c}\text { RD 2007-2013 } \\
\text { Competitiveness }\end{array}$ & $\begin{array}{c}\text { RD 2014-2020 } \\
\text { Stimuli for transfer of knowledge and innovation in the } \\
\text { field of agriculture and forestry in rural areas }\end{array}$ \\
$\begin{array}{c}\text { Improvement of quality of life and } \\
\text { diversification }\end{array}$ & $\begin{array}{c}\text { Competitiveness and viability of any type of agricultural } \\
\text { activities and business units }\end{array}$ \\
$\begin{array}{c}\text { Organization along the value chain and risk management } \\
\text { LEADER - Local Action Groups (LAGs) }\end{array}$ & $\begin{array}{c}\text { Sustaining ecosystems } \\
\text { Efficiency in utilizing natural resources and low carbon } \\
\text { sustainable economy }\end{array}$ \\
\hline & $\begin{array}{c}\text { Social inclusion, poverty alleviation and economic } \\
\text { development of rural areas }\end{array}$ \\
\hline Source: Department "Agro statistics" Ministry of Agriculture and Food in Bulgaria
\end{tabular}

\section{Conclusion}

Collective organization of production is assumed to be a sufficient choice taking into a consideration several reasons why mergers of existing farms promote efficiency: increase in optimal scale: combining farms may reduce duplication or otherwise benefit from an increased size; reduce transaction costs: an important source or transaction costs is opportunistic behavior. When farms agree to a future transaction, each farm may try to interpret the terms of a contract to its advantage. Similarly, a farmer that has more information than another - asymmetric information - may take 
advantage of the relatively ignorant farmer; synergies: farms that engage in different by complementary activities may benefit from mergers because of the economies of scope, where it is less costly for one farm to perform two activities than for two farms to perform them separately; and the improvement of management and coordination.

\section{Acknowledgement}

The research leading to these results has received funding from the People Programme (Marie Curie Actions) of the European Union's Seventh Framework Programme FP7/2007-2013/under REA Grant Agreement No. 611490 (PIAPP-GA-2013-611490)

\section{References}

Bryant, C, E. Mokrzycki (2006) The New Great Transformation? Change and Continuity in East-Central Europe, Abingdon, Taylor and Francis eBookstore (e-reprint of 1994 book)

Burawoy M., K. Verdery, (1999) Uncertain Transition: Ethnographies of Change in the Postsocialist World, Rowman \& Littlefield Publishers, Inc.

Chloupková J. (2002) European Cooperative Movement - Background and common denominators

Department "Agro statistics" Ministry of Agriculture and Food in Bulgaria

Hillborn L., (1998), The Impact of the European Union's Enlargement on Co-operatives. Prague 3-4 November 1997, p.5-6, available at: http://www.uwcc.wisc.edu/icic/orgs/ica/pubs/studies/The_Impact_of_the_EC/2.html

Jan Steijn A., (2007) Industrial Relations in the New Europe: Enlargement, Integration and Reform

Kornai, J. (1986) The Hungarian reform process: Visions, hopes and reality, Journal of Economic Literature, Vol. XXIV, pp.1687-1737

Offe, C. (1991) “Capitalism by democratic design?”, Democratic theory facing the triple transition in the East Central Europe", Social Research 58 (4), pp. 865-881

Regular Report from the European Commission on Bulgaria's progress towards accession, 1998

Sabates-Wheeler, R. (2005) "Cooperation in the Romanian Countryside: An Insight Into Post-Soviet Agriculture”, Lexington Books, p. 39

Swinnen, J. (1997) An explanation of land reform choices in Central and Eastern Europe, Policy Research Group Working Paper No. 5, http://citeseerx.ist.psu.edu/viewdoc/download?doi=10.1.1.485.1399\&rep=rep1\&type=pdf

Schilthuis G., Onno-Frank van Bekkum Uitgeverij Van Gorcum (2000) Agricultural Cooperatives in Central Europe: Trends and Issues in Preparation for EU Accession, Business \& Economics 
Appendix 1 Malmquist productivity index

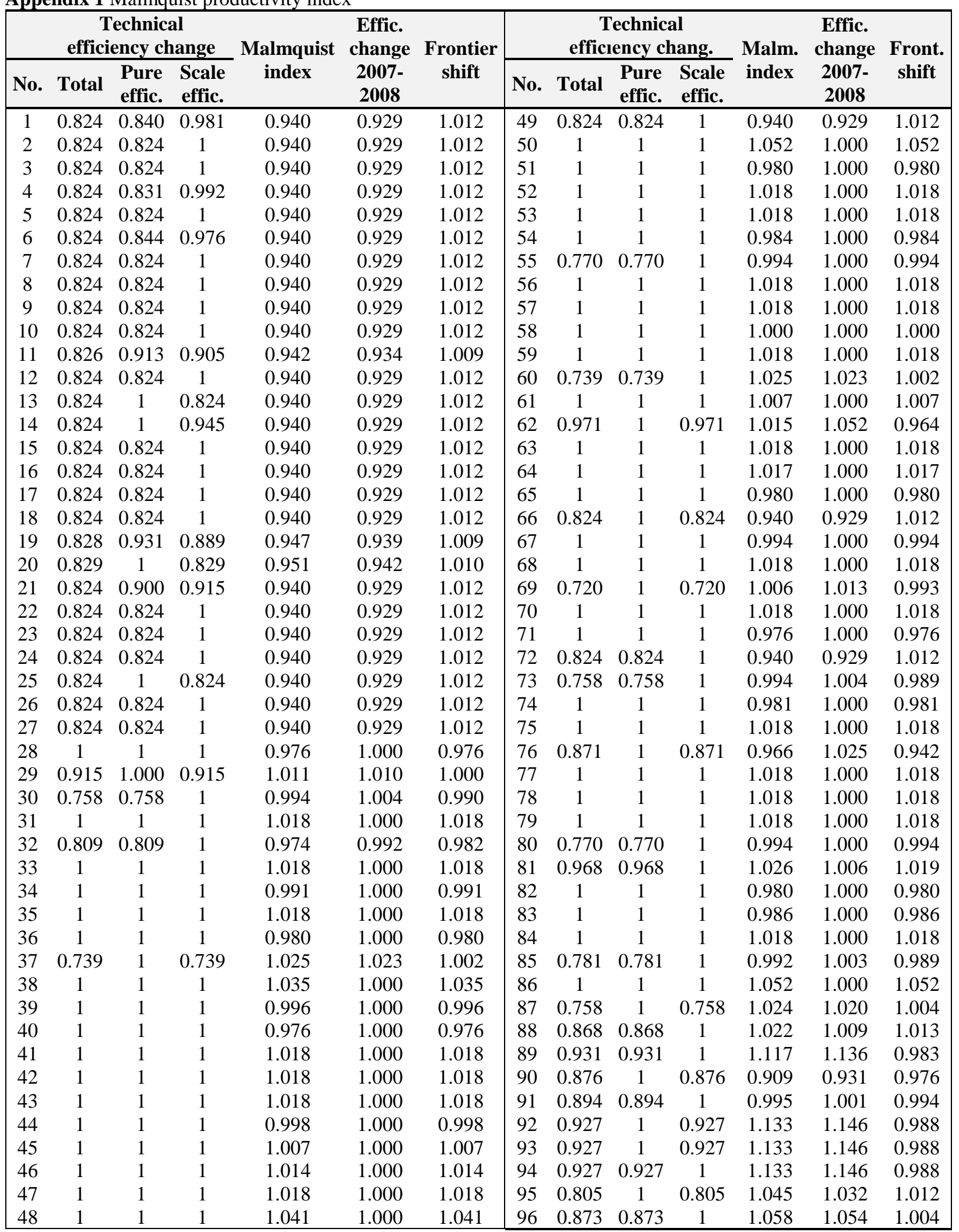

